\title{
Human Urine and Treated Domestic Effluent for Ornamental Sunflower Cultivation
}

\author{
Karoline S. Gonçalves ${ }^{1}$, Samir de S. Bandeira ${ }^{2}$, Gustavo A. Bispo ${ }^{2}$, Vital Pedro da S. Paz ${ }^{3}$, Hans R. Gheyi ${ }^{3}$ \\ \& Carlos Alberto da S. Ledo ${ }^{4}$ \\ ${ }^{1}$ Agricultural Engineering Graduate Program, Federal University of Recôncavo da Bahia, Cruz das Almas, \\ Bahia, Brazil \\ ${ }^{2}$ Federal University of Recôncavo da Bahia, Cruz das Almas, Bahia, Brazil \\ ${ }^{3}$ Nucleus of Water and Soil Engineering, Federal University of Recôncavo da Bahia, Cruz das Almas, Bahia, \\ Brazil \\ ${ }^{4}$ Brazilian Agricultural Research Corporation, National Center of Research on Cassava and Tropical Fruits, Cruz \\ das Almas, Bahia, Brazil \\ Correspondence: Karoline S. Gonçalves, Programa de Pós-Graduação em Engenharia Agrícola, Universidade \\ Federal do Recôncavo da Bahia, Cruz das Almas, Bahia, Brazil. Tel: 55-75-3621-2798. E-mail: \\ karolinesg@yahoo.com.br
}

Received: November 26, 2017

Accepted: December 30, 2017 Online Published: February 15, 2018

doi:10.5539/jas.v10n3p135

URL: https://doi.org/10.5539/jas.v10n3p135

\begin{abstract}
This study aimed to evaluate growth and production of ornamental sunflower (Helianthuns annuus L.), cv. Anão de Jardim, irrigated with dilutions of human urine in treated domestic effluent. The experiment was carried out in completely randomized design with five treatments and four replicates, in a greenhouse. Treatments consisted of four dilutions of human urine $(0,2,4$ and $6 \%$ ) in treated domestic effluent and fertilization with $50 \%$ of the recommendation of mineral fertilizer. Plants irrigated with human urine dilutions $(2,4$ and 6\%) in treated domestic effluent and fertilized with $50 \%$ of the recommendation of nitrogen $(\mathrm{N})$ and potassium $(\mathrm{K})$ showed reductions of growth and production, while those irrigated with $0 \%$ human urine dilution in treated domestic effluent and fertilized with $50 \%$ of $\mathrm{N}$ and $\mathrm{K}$ recommendation exhibited similar performance to those irrigated with public-supply water and fertilized with $100 \%$ of the recommendation of mineral fertilizer. The obtained results allow to infer on the viability of replacing public-supply water by treated domestic effluent for irrigation, with reduction of $50 \%$ in $\mathrm{N}$ and $\mathrm{K}$ fertilization, without prejudice to the growth and production of ornamental sunflower plants, cv. Anão de Jardim.
\end{abstract}

Keywords: Helianthuns annuus L., nitrogen, wastewater

\section{Introduction}

Sunflower production has great economic importance and potential as ornamental plant due to factors related to the crop, such as short cycle, easy propagation and cultivation, and especially because its inflorescence has postharvest durability and is very beautiful and attractive. Sunflower can be grown in any region of Brazil, especially for the characteristics of rusticity and easy management, for exhibiting high adaptation to the various climates in Brazil and for being little influenced by photoperiod, latitude and longitude (Zobiole, Castro, Oliveira, \& Oliveira Junior, 2010), representing an important species for the sector of flowers and ornamental plants.

In Northeast Brazil, flower production is mainly concentrated in the states Pernambuco, Bahia, Ceará and Alagoas (Brainer \& Oliveira, 2007), limited to areas with favorable climatic conditions and available water resources. However, the increasing scarcity of water and high cost of chemical fertilizers have limited the expansion of enterprises of floriculture, causing concern in the producers and increasing the interest in the search for alternative sources of water and nutrients.

Wastewater use in agriculture has significantly increased, especially due to the increasing difficulty to identify alternative water sources for irrigation and to the high cost of chemical fertilizers and also treatment systems for discharge of effluents into receiving bodies (Hespanhol, 2003). In addition to these factors, water reuse is a strategic element in the integrated management of water resources, since it increases the offer and meets the 
water demand of the agricultural sector, besides providing nutrients (Rebouças, Dias, Gonzaga, Gheyi, \& Sousa Neto, 2010). Larsen et al. (2001) report that human urine constitutes about $1 \%$ of the total volume of the domestic effluent, but represents more than $80 \%$ of the nitrogen $(\mathrm{N})$ and potassium $(\mathrm{K})$ found in the effluent. Besides having macro- and micronutrients essential to crops and in greater amount, human urine supplies them in the ideal form to be used by plants, i.e., $\mathrm{N}$ in the form of urea, phosphorus (P) in the form of orthophosphate and $\mathrm{K}$ as free ion (Jönsson, Baky, Jeppsson, Hellström, \& Kärraman, 2005).

According to Stintzing, Rodhe, Akerhielm, and Steineck (2002), if fertilization with urine is performed carefully and at adequate time, with direct application in the soil, the crop can absorb almost all N. Because of that, urine has been considered as an important element for management and conservation of water resources, since it can be recovered, besides constituting an important source of fertilizers for agriculture (Karak \& Bhattacharyya, 2011). Studies have demonstrated that the use of wastewater and/or human urine to irrigate plants results in positive aspects, since sanitary sewers are able to meet the water demand of the crops, as well as to provide sufficient nutrients to meet most of the nutritional requirements (Souza, Nobre, Gheyi, Dias, \& Soares, 2010; Andrade, Gheyi, Nobre, Dias, \& Nascimento, 2012; Santos et al., 2012; Santos Júnior, Souza, Pérez-Marin, Cavalcante, \& Medeiros, 2015).

Given the water and nutritional potential of wastewater from treated domestic effluent and human urine for ornamental sunflower production, studies demonstrating technical viability and hence reduction of costs with mineral fertilization are still incipient. Therefore, this study aimed to evaluate growth and production of ornamental sunflower (Helianthuns annuиs L.), cv. Anão de Jardim, irrigated with different dilutions of human urine in treated domestic effluent.

\section{Material and Methods}

\subsection{Experiment Location and Design}

The experiment was carried out in a greenhouse in the experimental area of the Agricultural Engineering Graduate Program of the Federal University of Recôncavo da Bahia, located in the municipality of Cruz das Almas, Bahia, Brazil, from January to March 2016. The geographic coordinates of the municipality are $12^{\circ} 40^{\prime} 12^{\prime \prime} \mathrm{S}$ latitude and $39^{\circ} 6^{\prime} 7^{\prime \prime} \mathrm{W}$ longitude, at altitude of $220 \mathrm{~m}$. The climate of the region is classified as humid to sub-humid (D'Angiolella, Castro Neto, \& Coelho, 2000) and, according to Köppen's classification, as Aw to Am, with mean annual rainfall of $1,143 \mathrm{~mm}$.

The experiment was set in a completely randomized design with five treatments and four replicates, totaling twenty experimental plots. The experimental plot was composed of one $20 \mathrm{dm}^{3}$ plastic pot filled with moderate A cohesive Yellow Latosol with the following chemical characteristics: $\mathrm{pH}$ (water) $=5$; $\mathrm{OM}(\%)=1.65$; $\mathrm{SB}$ and CEC $\left(\mathrm{cmol}_{\mathrm{c}} \mathrm{dm}^{-3}\right)=1.54$ and 4.79, respectively, and physical characteristics: $776 \mathrm{~g} \mathrm{~kg}^{-1}$ of total sand total, $181 \mathrm{~g}$ $\mathrm{kg}^{-1}$ of clay and $43 \mathrm{~g} \mathrm{~kg}^{-1}$ of silt.

Three seedlings of Helianthuns annuus L., cv. Anão de Jardim, with two pairs of leaves, were transplanted to each pot and, one day prior to transplantation, the soil was fertilized with $\mathrm{P}\left(577 \mathrm{mg} \mathrm{kg}^{-1}\right)$ using monoammonium phosphate (MAP) as source, as recommended by Novais, Neves, and Barros (1991).

\subsection{Conduction and Application of Treatments}

Seedlings were daily irrigated using watering cans, applying a water depth sufficient to maintain soil moisture close to field capacity. The water volume applied in each pot was determined by the difference between the weight of each pot with soil at field capacity and the weight on the specific day of irrigation.

Treatments were applied 7 days after transplantation, irrigating the plants with human urine dilutions $(0,2,4$ and $6 \%$ ) in treated domestic effluent, and the control with public-supply water. The chemical analysis of the waters used in this study are shown in Table 1. Mineral fertilization with nitrogen and potassium (NK) was applied through the irrigation water, adding 100 or $50 \%$ of the recommendation of Novais et al. (1991), according to the treatments (Table 2) and split into three applications, at 7, 22 and 32 days after transplantation. Each pot in the control treatment received $1.9 \mathrm{~g}$ of urea and $6.25 \mathrm{~g}$ of potassium sulfate, while each pot in the treatments with human urine diluted in effluent received $0.95 \mathrm{~g}$ of urea and $3.125 \mathrm{~g}$ of potassium sulfate. The chemical characteristics of the waters used in this study are shown in Table 2 . 
Table 1. Chemical analysis of the waters used in the study

\begin{tabular}{|c|c|c|c|c|c|c|c|c|c|c|c|c|c|}
\hline Water & $\mathrm{pH}$ & $\mathbf{E C}_{\mathbf{w}}$ & $\mathbf{K}^{+}$ & $\mathrm{NO}_{3}^{-}$ & $\mathrm{NO}_{4}^{-}$ & $\mathrm{CO}_{3}$ & $\mathrm{HCO}_{3}$ & $\mathbf{N a}$ & $\mathrm{Ca}$ & Mg & $\mathrm{Cl}$ & $\mathrm{SO}_{4}$ & SAR \\
\hline & & $\mu \mathrm{S} \mathrm{cm}^{-1}$ & -------- & ------ & $-\mathrm{mg} \mathrm{L}^{-1}$ & - & --------- & - ---- & ------ & $\mathrm{mol}_{\mathrm{c}} \mathrm{I}$ & -ב--. & ---- & $\left(\mathrm{mmol}_{\mathrm{c}} \mathrm{L}^{-1}\right)^{0.5}$ \\
\hline TDE & 6.85 & 1392.0 & 29.00 & 2.18 & 11.10 & 0.00 & 1.76 & 6.42 & 0.81 & 1.56 & 5.75 & $\mathrm{P}$ & 8.34 \\
\hline PSW & 7.41 & 387.0 & 0.17 & - & - & A & 0.41 & 1.73 & 0.51 & 0.88 & 1.87 & $\mathrm{P}$ & 2.93 \\
\hline
\end{tabular}

Note. $\mathrm{TDE}=$ treated domestic effluent; $\mathrm{PSW}=$ public-supply water; $\mathrm{EC}_{\mathrm{w}}=$ electrical conductivity; $\mathrm{SAR}=$ Sodium adsorption ratio.

Table 2. Treatments studied in ornamental sunflower plants (Helianthuns annuus L.), cv. Anão de Jardim

\begin{tabular}{lll}
\hline Treatments & HU dilutions & NK fertilization \\
\hline T1 (Control) & $0 \% \mathrm{HU}+100 \% \mathrm{PSW}$ & $100 \%$ \\
$\mathrm{~T} 2$ & $0 \% \mathrm{HU}+100 \% \mathrm{TDE}$ & $50 \%$ \\
$\mathrm{~T} 3$ & $2 \% \mathrm{HU}+98 \% \mathrm{TDE}$ & $50 \%$ \\
$\mathrm{~T} 4$ & $4 \% \mathrm{HU}+96 \% \mathrm{TDE}$ & $50 \%$ \\
T5 & $6 \% \mathrm{HU}+94 \% \mathrm{TDE}$ & $50 \%$ \\
\hline
\end{tabular}

Note. HU: human urine; PSW: public-supply water; TDE: treated domestic effluent; NK: mineral fertilization with nitrogen and potassium.

\subsection{Evaluated Variables}

Three evaluations were made, the first one at 22 days after transplantation (DAT) in one plant per pot, measuring plant height (PH), stem diameter (SD) and number of leaves (NL), identifying them to repeat the measurements after 15 days and at harvest. In this first evaluation, another plant was collected to determine shoot fresh and dry matter (SFM and SDM, respectively) and leaf area (LA). The second evaluation was made at 37 DAT, performing biometric measurements (PH, SD and $\mathrm{NL}$ ) in the identified plants and collecting another plant to determine SFM, SDM and LA, leaving only one plant per pot. This remaining plant was monitored to determine the beginning of flowering (BF), and the last evaluation (harvest) was made as the capitulum full opening (CFO) occurred in each plant, according to the criteria of Castiglioni, Balla, Castro, and Silveira (1997).

After CFO was observed, plants were collected to measure biometric variables (PH, SD and NL) and production variables (SFM, SDM, LA, internal and external capitulum diameter-ICD and ECD, and capitulum fresh and dry matter-CFM and CDM).

\subsection{Statistical Analysis}

Data were subjected to analysis of variance by $\mathrm{F}$ test and treatment means were grouped by the Scott-Knott means grouping test at 0.05 probability level. Statistical analyses were performed using the software R 3.4.1 (R Development Core Team, 2017).

\section{Results and Discussion}

Treatments had significant effect $(p<0.05)$ on ornamental sunflower plants, cv. Anão de Jardim, for the variables stem diameter (SD), shoot fresh matter (SFM) and leaf area (LA), in the evaluation performed 22 days after transplantation (DAT); for the variables SD, SFM, shoot dry matter (SDM) and LA at 37 DAT, and for the variables plant height $(\mathrm{PH}), \mathrm{SD}$, SFM, SDM, LA, internal capitulum diameter (ICD), external capitulum diameter (ECD), capitulum fresh matter (CFM) and capitulum dry matter (CDM), at harvest (Table 3). 
Table 3. Analysis of variance summary for plant height (PH), stem diameter (SD), number of leaves (NL), shoot fresh matter (SFM), shoot dry matter (SDM), leaf area (LA), beginning of flowering (BF), capitulum full opening (CFO), internal capitulum diameter (ICD), external capitulum diameter (ECD), capitulum fresh matter (CFM) and capitulum dry matter (CDM) of ornamental sunflower plants, cv. Anão de Jardim, irrigated with different dilutions of human urine (HU) in treated domestic effluent (TDE) at 22 and 37 days after transplantation (DAT) and at harvest

\begin{tabular}{|c|c|c|c|c|c|c|c|}
\hline \multirow{3}{*}{ Source of variation } & \multirow{3}{*}{ DF } & \multicolumn{6}{|c|}{ Mean squares } \\
\hline & & \multicolumn{6}{|c|}{22 DAT } \\
\hline & & PH & SD & NL & SFM & SDM & LA \\
\hline HU+TDE (\%) & 4 & $5.35^{\mathrm{ns}}$ & $2.06^{*}$ & $3.92^{\mathrm{ns}}$ & $22.00^{*}$ & $0.21^{\mathrm{ns}}$ & $12808.85^{*}$ \\
\hline Residual & 15 & 4.61 & 0.34 & 3.82 & 6.43 & 0.09 & 3564.70 \\
\hline C.V. $(\%)$ & & 26.82 & 12.70 & 20.67 & 45.43 & 45.21 & 42.52 \\
\hline \multirow[t]{3}{*}{ Overall mean } & & 8.00 & 4.61 & 9.45 & 5.58 & 0.65 & 140.42 \\
\hline & & \multicolumn{6}{|c|}{37 DAT } \\
\hline & & PH & SD & NL & SFM & SDM & LA \\
\hline HU+TDE (\%) & 4 & $32.86^{\text {ns }}$ & $5.22^{*}$ & $4.45^{\mathrm{ns}}$ & $313.61^{*}$ & $3.95^{*}$ & $88011.55^{*}$ \\
\hline Residual & 15 & 29.07 & 0.61 & 7.33 & 35.79 & 0.40 & 14899.83 \\
\hline C.V. $(\%)$ & & 28.83 & 10.81 & 19.21 & 29.60 & 24.71 & 41.11 \\
\hline \multirow[t]{3}{*}{ Overall mean } & & 18.70 & 7.24 & 14.10 & 20.21 & 2.55 & 296.92 \\
\hline & & \multicolumn{6}{|c|}{ HARVEST } \\
\hline & & PH & SD & NL & SFM & SDM & LA \\
\hline HU+TDE (\%) & 4 & $257.32^{*}$ & $15.24^{*}$ & $5.87^{\mathrm{ns}}$ & $2399.21^{*}$ & $41.18^{*}$ & $478126.60^{*}$ \\
\hline Residual & 15 & 24.31 & 2.02 & 5.83 & 215.33 & 5.23 & 63479.88 \\
\hline C.V. $(\%)$ & & 14.91 & 16.28 & 17.52 & 32.88 & 38.76 & 37.81 \\
\hline \multirow[t]{2}{*}{ Overall mean } & & 33.06 & 8.74 & 13.76 & 45.62 & 6.02 & 682.17 \\
\hline & & BF & CFO & ICD & ECD & CFM & CDM \\
\hline HU+TDE (\%) & 4 & $27.05^{\text {ns }}$ & $42.82^{\mathrm{ns}}$ & $11.25^{*}$ & $17.90^{*}$ & $1706.97^{*}$ & $19.98^{*}$ \\
\hline Residual & 15 & 31.78 & 39.55 & 2.18 & 2.68 & 216.59 & 3.35 \\
\hline C.V. (\%) & & 10.94 & 10.69 & 28.37 & 12.70 & 39.54 & 41.50 \\
\hline Overall mean & & 51.55 & 58.85 & 5.21 & 12.95 & 38.14 & 4.50 \\
\hline
\end{tabular}

Note. ${ }^{*}$ Significant and ${ }^{\mathrm{ns}}$ not significant at 0.05 probability level by F test. C.V.: coefficient of variation.

At 22 and 37 DAT, plants did not differ statistically for height (Tables 4 and 5). However, at harvest there was difference in plant height, and the highest means were observed in sunflower plants irrigated with the highest dilution of human urine in the effluent $(0 \% \mathrm{HU}+100 \% \mathrm{TDE})$ and fertilized with $50 \%$ of the $\mathrm{N}$ and $\mathrm{K}$ recommendation, and in sunflower plants irrigated with public-supply water and fertilized with $100 \%$ of the mineral fertilizer recommendation (Table 6).

Studies with reuse of effluent have demonstrated satisfactory results for plant growth in comparison to chemical fertilization. The results found in the present study for plant height corroborate those reported by other authors (Souza et al., 2010; Andrade et al., 2012; Freitas et al., 2012), who observed increment in the height of plants irrigated with wastewater. The increment in mean PH observed in sunflower plants irrigated with $100 \%$ domestic effluent is probably due to the content of nutrients dissolved in the domestic effluent.

At harvest, significant reduction occurred in the height of plants irrigated with the lowest dilutions of human urine in treated domestic effluent $(2,4$ and $6 \%$ of $\mathrm{HU})$, and such reduction was more accentuated as the urine became less diluted (Table 6). Plant height consists in the length of the flower stem and is an important parameter for production and commercialization of cut flowers because, along with other characteristics, such as quality and durability of inflorescence, it determines the economic value of the product in the market. According to Neves, Andréo, Watanabe, Fazio, and Boaro (2009), the minimum length the flower stem of ornamental sunflower must have to meet the commercial standards is $35 \mathrm{~cm}$. Only plants in the treatment irrigated with the highest dilution of human urine in domestic effluent $(0 \% \mathrm{HU}+100 \% \mathrm{TDE})$ and in the treatment irrigated with public-supply water (control) exhibit mean height above the recommended value (Table 6). 
Table 4. Means of plant height (PH), stem diameter (SD), number of leaves (NL), shoot fresh matter (SFM), shoot dry matter (SDM) and leaf area (LA) of ornamental sunflower plants, cv. Anão de Jardim, subjected to irrigation with different dilutions of human urine in treated domestic effluent at 22 days after transplantation

\begin{tabular}{lllllll}
\hline Treatments & PH $(\mathbf{c m})$ & SD $(\mathbf{m m})$ & NL & SFM $(\mathbf{g})$ & SDM $(\mathbf{g})$ & LA $\left(\mathbf{c m}^{2}\right)$ \\
\hline $100 \%$ PSW+100\% NK & $9.37 \mathrm{a}$ & $5.24 \mathrm{a}$ & $10.75 \mathrm{a}$ & $8.56 \mathrm{a}$ & $0.85 \mathrm{a}$ & $223.20 \mathrm{a}$ \\
$100 \%$ TDE $+0 \%$ HU+50\%NK & $9.00 \mathrm{a}$ & $5.49 \mathrm{a}$ & $9.75 \mathrm{a}$ & $7.44 \mathrm{a}$ & $0.82 \mathrm{a}$ & $170.30 \mathrm{a}$ \\
$98 \% \mathrm{TDE}+2 \% \mathrm{HU}+50 \% \mathrm{NK}$ & $7.52 \mathrm{a}$ & $4.33 \mathrm{~b}$ & $9.25 \mathrm{a}$ & $3.52 \mathrm{~b}$ & $0.40 \mathrm{~b}$ & $96.63 \mathrm{~b}$ \\
$96 \% \mathrm{TDE}+4 \% \mathrm{HU}+50 \% \mathrm{NK}$ & $6.57 \mathrm{a}$ & $3.80 \mathrm{~b}$ & $8.00 \mathrm{a}$ & $3.30 \mathrm{~b}$ & $0.40 \mathrm{~b}$ & $86.32 \mathrm{~b}$ \\
$94 \% \mathrm{TDE}+6 \% \mathrm{HU}+50 \% \mathrm{NK}$ & $7.55 \mathrm{a}$ & $4.22 \mathrm{~b}$ & $9.50 \mathrm{a}$ & $5.10 \mathrm{~b}$ & $0.78 \mathrm{a}$ & $125.63 \mathrm{~b}$ \\
\hline
\end{tabular}

Note. Means followed by the same letter belong to the same group, according to the Scott-Knott test at 0.05 probability level. PSW: public-supply water; NK: fertilization with nitrogen and potassium; TDE: treated domestic effluent; HU: human urine.

Table 5. Means of plant height (PH), stem diameter (SD), number of leaves (NL), shoot fresh matter (SFM), shoot dry matter (SDM) and leaf area (LA) of ornamental sunflower plants, cv. Anão de Jardim, subjected to irrigation with different dilutions of human urine in treated domestic effluent at 37 days after transplantation

\begin{tabular}{lllllll}
\hline Treatments & PH $(\mathbf{c m})$ & SD $(\mathbf{m m})$ & NL & SFM (g) & SDM $(\mathbf{g})$ & LA $\left(\mathbf{c m}^{2}\right)$ \\
\hline $100 \%$ PSW+100\% NK & $21.20 \mathrm{a}$ & $7.86 \mathrm{a}$ & $14.75 \mathrm{a}$ & $33.54 \mathrm{a}$ & $3.91 \mathrm{a}$ & $535.54 \mathrm{a}$ \\
$100 \%$ TDE $+0 \%$ HU+50\%NK & $22.10 \mathrm{a}$ & $8.74 \mathrm{a}$ & $14.50 \mathrm{a}$ & $20.84 \mathrm{~b}$ & $2.51 \mathrm{~b}$ & $283.74 \mathrm{~b}$ \\
$98 \% \mathrm{TDE}+2 \% \mathrm{HU}+50 \% \mathrm{NK}$ & $18.02 \mathrm{a}$ & $7.38 \mathrm{a}$ & $12.75 \mathrm{a}$ & $22.33 \mathrm{~b}$ & $3.13 \mathrm{a}$ & $318.09 \mathrm{~b}$ \\
$96 \% \mathrm{TDE}+4 \% \mathrm{HU}+50 \% \mathrm{NK}$ & $15.40 \mathrm{a}$ & $6.03 \mathrm{a}$ & $13.25 \mathrm{a}$ & $11.18 \mathrm{c}$ & $1.58 \mathrm{~b}$ & $169.34 \mathrm{~b}$ \\
$94 \% \mathrm{TDE}+6 \% \mathrm{HU}+50 \% \mathrm{NK}$ & $16.77 \mathrm{a}$ & $6.20 \mathrm{a}$ & $15.25 \mathrm{a}$ & $13.18 \mathrm{c}$ & $1.64 \mathrm{~b}$ & $177.88 \mathrm{~b}$ \\
\hline
\end{tabular}

Note. Means followed by the same letter belong to the same group, according to the Scott-Knott test at 0.05 probability level. PSW: public-supply water; NK: fertilization with nitrogen and potassium; TDE: treated domestic effluent; HU: human urine.

Table 6. Means of plant height (PH), stem diameter (SD), number of leaves (NL), shoot fresh matter (SFM), shoot dry matter (SDM), leaf area (LA), beginning of flowering (BF), capitulum full opening (CFO), internal capitulum diameter (ICD), external capitulum diameter (ECD), capitulum fresh matter (CFM) and capitulum dry matter (CDM) of ornamental sunflower plants, cv. Anão de Jardim, subjected to irrigation with different dilutions of human urine in treated domestic effluent at harvest

\begin{tabular}{|c|c|c|c|c|c|c|}
\hline Treatments & PH (cm) & SD (mm) & NL & SFM (g) & SDM (g) & $\mathbf{L A}\left(\mathrm{cm}^{2}\right)$ \\
\hline $100 \% \mathrm{PSW}+100 \% \mathrm{NK}$ & $40.40 \mathrm{a}$ & $10.81 \mathrm{a}$ & $13.33 \mathrm{a}$ & $64.53 \mathrm{a}$ & $8.33 \mathrm{a}$ & $983.83 \mathrm{a}$ \\
\hline $100 \% \mathrm{TDE}+0 \% \mathrm{HU}+50 \% \mathrm{NK}$ & $42.75 \mathrm{a}$ & $10.86 \mathrm{a}$ & $15.50 \mathrm{a}$ & $79.06 \mathrm{a}$ & $10.49 \mathrm{a}$ & $1133.07 \mathrm{a}$ \\
\hline $98 \% \mathrm{TDE}+2 \% \mathrm{HU}+50 \% \mathrm{NK}$ & $30.25 \mathrm{~b}$ & $7.94 \mathrm{~b}$ & $13.00 \mathrm{a}$ & $36.50 \mathrm{~b}$ & $4.90 \mathrm{~b}$ & $543.21 \mathrm{~b}$ \\
\hline $96 \% \mathrm{TDE}+4 \% \mathrm{HU}+50 \% \mathrm{NK}$ & $26.47 \mathrm{~b}$ & $7.12 \mathrm{~b}$ & $12.50 \mathrm{a}$ & $23.71 \mathrm{~b}$ & $3.08 \mathrm{~b}$ & $365.15 \mathrm{~b}$ \\
\hline $94 \% \mathrm{TDE}+6 \% \mathrm{HU}+50 \% \mathrm{NK}$ & $25.42 \mathrm{~b}$ & $6.95 \mathrm{~b}$ & $14.50 \mathrm{a}$ & $24.30 \mathrm{~b}$ & $3.30 \mathrm{~b}$ & $385.59 \mathrm{~b}$ \\
\hline Treatments & BF (days) & CFO (days) & ICD (cm) & ECD (cm) & CFM (g) & CDM (g) \\
\hline $100 \% \mathrm{PSW}+100 \% \mathrm{NK}$ & $54.75 \mathrm{a}$ & $62.75 \mathrm{a}$ & $7.25 \mathrm{a}$ & $14.07 \mathrm{a}$ & $55.55 \mathrm{a}$ & $6.04 \mathrm{a}$ \\
\hline $100 \% \mathrm{TDE}+0 \% \mathrm{HU}+50 \% \mathrm{NK}$ & $54.00 \mathrm{a}$ & $62.00 \mathrm{a}$ & $6.67 \mathrm{a}$ & $15.92 \mathrm{a}$ & $64.84 \mathrm{a}$ & $7.57 \mathrm{a}$ \\
\hline $98 \% \mathrm{TDE}+2 \% \mathrm{HU}+50 \% \mathrm{NK}$ & $50.00 \mathrm{a}$ & $57.25 \mathrm{a}$ & $4.70 \mathrm{~b}$ & $12.90 \mathrm{~b}$ & $32.29 \mathrm{~b}$ & $3.98 \mathrm{~b}$ \\
\hline $96 \% \mathrm{TDE}+4 \% \mathrm{HU}+50 \% \mathrm{NK}$ & $49.50 \mathrm{a}$ & $55.75 \mathrm{a}$ & $3.40 \mathrm{~b}$ & $10.70 \mathrm{~b}$ & $17.49 \mathrm{~b}$ & $2.18 \mathrm{~b}$ \\
\hline $94 \% \mathrm{TDE}+6 \% \mathrm{HU}+50 \% \mathrm{NK}$ & $49.50 \mathrm{a}$ & $56.50 \mathrm{a}$ & $4.02 \mathrm{~b}$ & $11.20 \mathrm{~b}$ & $20.52 \mathrm{~b}$ & $2.71 \mathrm{~b}$ \\
\hline
\end{tabular}

Note. Means followed by the same letter belong to the same group, according to the Scott-Knott test at 0.05 probability level. PSW: public-supply water; NK: fertilization with nitrogen and potassium; TDE: treated domestic effluent; HU: human urine.

Plants irrigated with the highest dilution of human urine in the domestic effluent $(0 \% \mathrm{HU}+100 \%$ TDE) or public-supply water (control) showed the highest means of SD and did not differ significantly. However, thinner stems were observed in sunflower plants irrigated with the lowest dilutions of human urine in domestic effluent $(2,4$ and $6 \% \mathrm{HU})$ in the evaluations at 22 DAT and at harvest (Tables 4 and 6). Andrade et al. (2012) and Freitas 
et al. (2012) observed increment in SD of sunflower plants irrigated with wastewater, compared with those irrigated with public-supply water.

In the harvest of flower stems, all treatments met the limit range from 5 to $15 \mathrm{~mm}$, established as quality standard for SD in ornamental sunflower plants (Grieve \& Poss, 2010) (Table 6). According to Curti (2010), it is desirable that the flower stem have greater diameter and resistance to support the inflorescence, which is heavier in sunflower plants compared with other species of cut flowers.

The means of NL did not differ in the three evaluations, with values of 9.45, 14.10 and 13.76 leaves at 22 DAT, 37 DAT and at harvest, respectively (Table 3). Oliveira, Paz, Gonçalves, and Oliveira (2017), in study with ornamental sunflower plants, cv. Anão de Jardim, irrigated with different dilutions of wastewater, observed higher means of number of leaves at 35 days after transplanting (19.27 leaves) and at harvest, 56 days after transplanting (30.05 leaves). The non-significant effect on NL as a function of the dilutions of human urine reveals that, as the $\mathrm{N}$ compounds, other nutrients present in the urine and in the effluent may have acted in favor of the better result of NL. Another probable explanation for the absence of influence of the different dilutions of human urine on the number of leaves is that, in the sunflower crop, the number of leaves is defined very early, between 10 and 20 days after emergence, in the period of leaf differentiation (Merrien, 1992). Hence, since treatments started 18 days after emergence, it is possible that the number of leaves had already been defined previously. Corroborating the results obtained for NL, Freitas et al. (2012) also observed no significant differences as a function of the $\mathrm{N}$ doses applied in sunflower plants, cv. Multissol.

Although no significant differences were observed between the NL of ornamental sunflower plants as a function of the studied treatments, plants irrigated with the lowest dilutions of urine in effluent $(2,4$ and $6 \%)$ showed reduction in leaf area in all evaluations (Tables 4, 5 and 6). It is believed that this reduction may have been a consequence of the nutritional imbalance caused by the highest dilutions of urine in domestic effluent. Such imbalance may have caused an increment in the concentration of ions in the soil solution, reducing the osmotic potential and compromising water absorption by plants. According to Taiz et al. (2017), leaf expansion is very sensitive to water deficit and is reduced at moderate levels of stress, consequently leading to reduction in shoot biomass production and photosynthetic efficiency.

At 22 DAT, there was a reduction of SFM in plants irrigated with the lowest dilutions of human urine in treated domestic effluent $(2,4$ and $6 \% \mathrm{HU})$, followed by reduction of SDM in plants irrigated with dilutions of 2 or $4 \%$ of urine in effluent (Table 4). In the second evaluation, at 37 DAT, SFM decreased in plants irrigated with urine diluted in effluent, and only plants irrigated with $2 \%$ dilution of human urine in domestic effluent maintained the mean SDM equal to the control, irrigated with public-supply water (Table 5). At harvest, the means of SFM and SDM were also reduced in plants irrigated with dilutions of urine in domestic effluent, except for plants irrigated with dilution of $0 \% \mathrm{HU}+100 \%$ TDE, which showed SFM and SDM means equal to those of plants irrigated with public-supply water (Table 6).

Corroborating the results found in the present study, Araújo, Coura, Oliveira, Sabino, and Oliveira (2015) observed that human urine concentrations above 3\% in the hydroponic solution led to loss of shoot fresh matter, while urine concentrations above $0 \%$ caused reduction in the shoot dry matter of corn plants, attributing this reduction to the high concentrations of chloride and sodium found in the urine dilutions. Nevertheless, Santos Júnior et al. (2015) concluded that the addition of 4.5\% human urine in domestic effluent applied via irrigation in millet plants cultivated in Chromic Luvisol led to production results similar to those observed in plants under the recommended mineral fertilization and irrigated with public-supply water.

Regarding the use of irrigation with wastewater compared with public-supply water, Souza et al. (2010), studying the sunflower crop irrigated with wastewater and public-supply water and four doses of earthworm humus, observed that plants under wastewater irrigation accumulated more shoot fresh and dry matter than plants irrigated with public-supply water. Deon, Gomes, Melfi, Montes, and Silva (2010) and Souza et al. (2010) highlight the importance of the content of mineral elements present in effluents, especially macro- and micronutrients, as factors of contribution to a good plant development.

The beginning of flowering (BF) occurred on average at 51.5 days after transplantation, and plants irrigated with the lowest dilutions of human urine ( 4 and $6 \%$ ) were the first ones to start flowering, on average at 49.5 days, with capitulum full opening (CFO) at 55.7 days in plants irrigated with 4\% human urine dilution in effluent (Tables 3 and 6). Although no significant difference was observed between treatment means, there was a shorter period for BF and CFO in plants irrigated with the dilutions of human urine in effluent (Table 6). Sunflower plants irrigated with public-supply water and fertilized with $100 \%$ of the mineral fertilization recommendation showed later BF. Likewise, Oliveira et al. (2017) obtained similar results in the cultivation of ornamental 
sunflower plants (cv. Anão de Jardim) irrigated with wastewater dilutions and did not observe significant differences between treatment means for the variables BF and CFO, which occurred on average at 49 and 52 days, respectively. Andrade et al. (2012) also did not observe significant differences for the variables beginning of flowering (BF) and capitulum full opening (CFO) in a study with different genotypes of ornamental sunflower irrigated with treated wastewater and public-supply water.

Although plants in the treatment with $4 \%$ human urine dilution in treated effluent were early regarding BF and $\mathrm{CFO}$, the parameters internal capitulum diameter (ICD), external capitulum diameter (ECD), capitulum fresh matter (CFM) and capitulum dry matter (CDM) were reduced in this treatment. Capitula of sunflower irrigated with public-supply water or $0 \%$ human urine dilution in effluent were showier and larger, with higher means of diameter and mass, not differing statistically (Table 6). Freitas et al. (2012) concluded that the partial replacement of commercial $\mathrm{N}$ by the $\mathrm{N}$ present in reuse water maintains the mean capitulum diameter equal to that of plants irrigated with public-supply water and fertilized with mineral fertilizer, and recommended treated domestic sewage water for use in sunflower cultivation.

According to Deon et al. (2010), the presence of nutrients in the effluent can partially replace $\mathrm{N}$ fertilization, which may probably have influenced and favored the greater capitulum diameter obtained in sunflower plants irrigated with $100 \%$ treated domestic effluent. Other studies with the sunflower crop have found increments in internal and external capitulum diameter of plants irrigated with wastewater in comparison to those irrigated with public-supply water (Souza et al., 2010; Andrade et al., 2012; Freitas et al., 2012). Corroborating the results found, Biscaro et al. (2008) also observed increase in capitulum diameter in sunflower, cv. H 358 from Dekalb, as a function of the increase in $\mathrm{N}$ doses, obtaining maximum estimated diameter of $11.9 \mathrm{~cm}$ with the $\mathrm{N}$ dose of $44.9 \mathrm{~kg} \mathrm{ha}^{-1}$ and, from this point on, reductions in capitulum diameter as $\mathrm{N}$ doses increased. Capitulum diameter in cut flowers is one of the morphological features most affected by the addition of N (Souza et al., 2010), a macronutrient present in abundance in human urine. Addition of low $\mathrm{N}$ doses $\left(25 \mathrm{~kg} \mathrm{ha}^{-1}\right)$ may cause significant increase in capitulum diameter, while high doses may lead to damages (Biscaro et al., 2008).

Despite the reductions of ECD in plants irrigated with the lowest dilutions of human urine (2, 4 and 6\%), all treatments showed means within the acceptable commercial standard, which according to Sakata Seed Corporation (2003) is between 10 and $15 \mathrm{~cm}$, and the highest value of ECD occurred in plants irrigated with $100 \%$ effluent $(15.92 \mathrm{~cm})$. Other studies have found ECD varying from 15.0 to $18.6 \mathrm{~cm}$, depending on the cultivar (Smiderle, Mourão, \& Gianluppi, 2005; Silva, Bezerra, Sousa, Pereira Filho, \& Freitas, 2011).

At harvest, ornamental sunflower plants irrigated with the lowest dilutions of human urine in domestic effluent $(2,4$ and $6 \%)$ showed the greatest reductions in the growth and production variables evaluated (Table 6).

Considering the results obtained in the present study for growth and production of ornamental sunflower, cv. Anão de Jardim, it is possible to infer on the recommendation of irrigation only with $0 \%$ human urine dilution in treated domestic effluent, without damages to the crop.

\section{Conclusions}

Dilutions of 2, 4 and $6 \%$ of human urine in treated domestic effluent led to reductions in growth and production variables of ornamental sunflower plants, cv. Anão de Jardim;

Ornamental sunflower plants, cv. Anão de Jardim, irrigated with $0 \%$ human urine dilution in treated domestic effluent and fertilized with $50 \%$ of nitrogen and potassium recommendation showed growth and production similar to those of plants irrigated with public-supply water and fertilized with $100 \%$ of the mineral fertilizer recommendation, evidencing the possibility of replacing irrigation with public-supply water by treated domestic effluent, along with reduction from $100 \%$ to $50 \%$ of the mineral fertilization recommendation, without damages to growth and production.

\section{References}

Andrade, L. O. de, Gheyi, H. R., Nobre, R. G., Dias, N. da S., \& Nascimento, E. C. S. N. (2012). Qualidade de flores de girassóis ornamentais irrigados com águas residuária e de abastecimento. Idesia, 30, 19-27. https://doi.org/10.4067/S0718-34292012000200003

Araújo, N. C. de, Coura, M. de A., Oliveira, R. de, Sabino, E. M. B., \& Oliveira, S. J. C. (2015). Cultivo hidropônico de milho fertirrigado com urina humana como fonte alternativa de nutrientes. Irriga, 20(4), 718-729. https://doi.org/10.15809/irriga.2015v20n4p718 
Biscaro, G. A., Machado, J. R., Tosta, M. da S., Mendonça, V., Soratto, R. P., \& Carvalho, L. A de. (2008). Adubação nitrogenada em cobertura no girassol irrigado nas condições de Cassilândia-MS. Ciência e Agrotecnologia, 32, 1366-1373. https://doi.org/10.1590/S1413-70542008000500002

Brainer, M. S. de C. P., \& Oliveira, A. A. P. (2007). Floricultura: Perfil da atividade no nordeste brasileiro (p. 20). Série Documentos do ETENE, n.17. Fortaleza: Banco do Nordeste do Brasil.

Castiglioni, V. B. R., Balla, A., Castro, C. de, \& Silveira, J. M. (1997). Fases de desenvolvimento da planta de girassol (p. 26). Londrina: EMBRAPA-CNPS.

Curti, G. L. (2010). Caracterização de cultivares de girassol ornamental semeados em diferentes épocas no Oeste Catarinense (Dissertação de Mestrado, Universidade Federal do Paraná, Pato Branco, Brasil). Retrieved from http://repositorio.utfpr.edu.br/jspui/handle/1/242

D’Angiolella, G. L. B. Castro Neto, M. T., \& Coelho, E. F. (2000). Tendências climáticas para os Tabuleiros Costeiros da região de Cruz das Almas, Bahia. Revista Bahia Agrícola, 4, 14-16. Retrieved from http://www.seagri.ba.gov.br/sites/default/files/comunicacoes_V4N1.pdf

Deon, M. D., Gomes, T. M., Melfi, A. J., Montes, C. R., \& Silva, E. da. (2010). Produtividade e qualidade da cana-de-açúcar irrigada com efluente de estação de tratamento de esgoto. Pesquisa Agropecuária Brasileira, 45, 1149-1156. https://doi.org/10.1590/S0100-204X2010001000014

Freitas, C. A. S. de, Silva, A. R. A. da, Bezerra, F. M. L., Andrade, R. R. de, Mota, F. S. B., \& Aquino, B. F. de. (2012). Crescimento da cultura do girassol irrigado com diferentes tipos de água e adubação nitrogenada. Revista Brasileira de Engenharia Agrícola e Ambiental, 16(10), 1031-1039. https://doi.org/10.1590/ S1415-43662012001000001

Grieve, C. M., \& Poss, J. A. (2010). Response of ornamental sunflower cultivars 'Sunbeam' and 'Moonbright' to irrigation with saline wastewaters. Journal of Plant Nutrition, 33, 1579-1592. https://doi.org/10.1080/ 01904167.2010 .496883

Hespanhol, I. (2003). Potencial de reúso de água no Brasil-Agricultura, indústria, municípios, recarga de aquíferos. In C. S. A. Mancuso \& H. F. Santos (Eds.), Reúso de água (pp. 37-95). Barueri: Manole. https://doi.org/10.21168/rbrh.v7n4.p75-95

Jönsson, H., Baky, A., Jeppsson, U., Hellström, D., \& Kärraman, E. (2005). Composition of urine, faeces, greywater and biowaste for utilization in the URWARE model. The Mistra Programme Urban Water (p. 49). Gothenburg: Chalmers University of Technology. Retrieved from http://www.iea.lth.se/publications/ Reports/LTH-IEA-7222.pdf

Karak, T., \& Bhattacharyya, P. (2011). Human urine as a source of alternative natural fertilizer in agriculture: A flight of fancy or an achievable reality. Resources, Conservation and Recycling, 55, 400-408. https://doi.org/10.1016/j.resconrec.2010.12.008

Larsen, T. A., Peters, I., Alder, A., Eggen, R., Mauren, M., \& Muncke, J. (2001). Re-engineering the toilet for sustainable wastewater management. Environmental Science Technologies, 35(9), 192-197. https://doi.org/ $10.1021 / \mathrm{es} 012328 \mathrm{~d}$

Merrien, A. (1992). Physiologie du tournesol (p. 66). Paris: CETION.

Neves, M. B., Andréo, Y. de S., Watanabe, A. A., Fazio, J. L. de, \& Boaro, C. S. F. (2009). Uso de daminozide na produção de girassol ornamental cultivados em vaso. Revista Eletrônica de Agronomia, 16, 31-37. Retrieved from http://www.faef.revista.inf.br/imagens_arquivos/arquivos_destaque/QAIImt1fKRyJAwn 2013-5-10-15-35-30.pdf

Novais, R. F., Neves, J. C. L., \& Barros, N. F. (1991). Ensaio em ambiente controlado. In A. J. Oliveira, W. E. Garrido, J. D. Araújo, \& S. Lourenço (Eds.), Métodos de pesquisa em fertilidade do solo (pp. 189-253). Brasília: Embrapa-SEA.

Oliveira, M. L. A., Paz, V. P. da S., Gonçalves, K. S., \& Oliveira, G. X. S. O. (2017). Crescimento e produção de girassol ornamental irrigado com diferentes lâminas e diluições de água residuária. Irriga, 22(1), $204-2019$. https://doi.org/10.15809/irriga.2017v22n1p204-219

R Development Core Team. (2017). R: A language and environment for statistical computing. R Foundation for Statistical Computing. Retrieved from http://www.R-project.org 
Rebouças, J. R. L., Dias, N. S., Gonzaga, M. I. S., Gheyi, H. R., \& Sousa Neto, O. N. (2010). Crescimento do feijão-caupi irrigado com água residuária de esgoto doméstico tratado. Revista Caatinga, 23, 97-102. Retrieved from file:///C:/Users/Hans\%20Raj\%20Gheyi/Downloads/1506-31567-1-PB.pdf

Sakata Seed Corporation. (2003). Sakata's reliable seeds: flower seed catalogue 2001-2003 (p. 99). Bragança Paulista: Sakata Sementes Agroflora.

Santos Júnior, J. A., Souza, C. F. de, Pérez-Marin, A. M., Cavalcante, A. R., \& Medeiros, S. de S. (2015). Interação urina e efluente doméstico na produção do milheto cultivado em solos do semiárido paraibano. Revista Brasileira de Engenharia Agrícola e Ambiental, 19(5), 456-463. https://doi.org/10.1590/1807-1929/ agriambi.v19n5p456-463

Santos, O. S. N., Paz, V. P. da, Gloaguen, T. V., Teixeira, M. B., Fadigas, F. de S., \& Costa, J. A. (2012). Crescimento e estado nutricional de helicônia irrigada com água residuária tratada em casa de vegetação. Revista Brasileira de Engenharia Agrícola e Ambiental, 16(8), 820-827. https://doi.org/10.1590/S141543662012000800002

Silva, A. R. A. da, Bezerra, F. M. L., Sousa, C. C. M. de, Pereira Filho, J. V., \& Freitas, C. A. S. de. (2011). Desempenho de cultivares de girassol sob diferentes lâminas de irrigação no Vale do Curu, CE. Revista Ciência Agronômica, 42, 57-64. https://doi.org/10.1590/S1806-66902011000100008

Smiderle, O. J., Mourão Júnior, M., \& Gianluppi, D. (2005). Avaliação de cultivares de girassol em savana de Roraima. Acta Amazônica, 35(3), 331-336. https://doi.org/10.1590/S0044-59672005000300004

Souza, R. M. de, Nobre, R. G., Gheyi, H. R., Dias, N. da S., \& Soares, F. A. L. (2010). Utilização de água residuária e de adubação orgânica no cultivo de girassol. Revista Caatinga, 233(2), 125-133. Retrieved from http://www.redalyc.org/articulo.oa?id=237116915016

Stintzing, A. R, Rodhe, L., Akerhielm, H., \& Steineck, S. (2002). Human urine as a fertilizer plant nutrients, application technique and environmental effects. Proceedings of the $10^{\text {th }}$ International Conference Ramiran Network (pp. 161-162). Retrieved from http://ramiran.uvlf.sk/DOC/C3.pdf

Taiz, L., Zeiger, E., Moller, I. M., \& Murphy, A. (2017). Fisiologia e desenvolvimento vegetal (6th ed., p. 888). Porto Alegre: Artmed.

Zobiole, L. H. S., Castro, C. de, Oliveira, F. A. de O., \& Oliveira Junior, A. de. (2010). Marcha de absorção de macronutrientes na cultura do girassol. Revista Brasileira de Ciência do Solo, 34, 425-433. https://doi.org/ $10.1590 / \mathrm{S} 0100-06832010000200016$

\section{Copyrights}

Copyright for this article is retained by the author(s), with first publication rights granted to the journal.

This is an open-access article distributed under the terms and conditions of the Creative Commons Attribution license (http://creativecommons.org/licenses/by/4.0/). 